\title{
Applying Best Practice Online Learning, Teaching, and Support to Intensive Online Environments: An Integrative Review
}

\author{
Chantal Roddy ${ }^{1 *}$, Danielle Lalaine Amiet ${ }^{1}$, Jennifer Chung ${ }^{1}$, Christopher Holt ${ }^{1}$, \\ Lauren Shaw', Stephen McKenzie', Filia Garivaldis ${ }^{1}$, Jason M. Lodge ${ }^{2}$ \\ and Matthew Edward Mundy ${ }^{3}$
}

\begin{abstract}
${ }^{1}$ Monash Online-Psychology Education Division (MO-PED), Faculty of Medicine, Nursing and Health Sciences, School of Psychological Sciences, Monash University, Clayton, VIC, Australia, ${ }^{2}$ Melbourne Centre for the Study of Higher Education, The University of Melbourne, Melbourne, VIC, Australia, ${ }^{3}$ Faculty of Medicine, Nursing and Health Sciences, School of Psychological Sciences, Monash Institute of Cognitive and Clinical Neurosciences, Monash University, Clayton, VIC, Australia
\end{abstract}

\section{OPEN ACCESS}

Edited by:

Rebecca C. Jordan,

Rutgers University, The State University of New Jersey,

United States

Reviewed by:

Sally Hamouda,

Cairo University, Egypt

Josephine Louise Vaughan,

University of Newcastle, Australia

*Correspondence:

Chantal Roddy

chantal.roddy@monash.edu

Specialty section:

This article was submitted

to Digital Education,

a section of the journal

Frontiers in Education

Received: 16 August 2017

Accepted: 26 October 2017

Published: 21 November 2017

Citation:

Roddy C, Amiet DL, Chung J, Holt C Shaw L, McKenzie S, Garivaldis F, Lodge JM and Mundy ME (2017)

Applying Best Practice Online

Learning, Teaching, and Support to Intensive Online Environments:

An Integrative Review.

Front. Educ. 2:59.

doi: 10.3389/feduc.2017.00059
Demand for flexible online offerings has continued to increase as prospective students seek to upskill, re-train, and undertake further study. Education institutions are moving to intensive modes of online study delivered in 6- to 8-week study periods which offer more frequent intake periods. Prior literature has established key success factors for nonintensive (12-13 weeks) online offerings; for teachers, skill development is critical to promote a flexible, responsive approach and maintain technological capabilities; for students, an ability to navigate the technology, interact with the learning environment in meaningful ways, and self-regulate learning is important, as the absence of physical infrastructure and opportunities for face-to-face interactions in online environments places a greater emphasis on alternate forms of communication and support. The current paper explores known best practice principles for online instructors, students, and student support and considers how these might apply to intensive online environments. It is suggested that the accelerated nature of learning in intensive settings may place additional demands on students, instructors, and support mechanisms. Further research is imperative to determine predictors of success in online intensive learning environments.

Keywords: online education, intensive online learning, student experience, teacher education, higher education

The scope and availability of online offerings continues to expand globally. Demand for more intensive, short-term courses that provide opportunities for up-skilling has increased in the wake of massive open online courses (MOOCs), and this increased demand has in turn expanded the availability of online degree programs. As many as six million students in the USA were undertaking online education in 2015, with nearly five million of these students studying an undergraduate college (tertiary) qualification (Allen and Seaman, 2017). Similar trends have been noted in the Australian context. Recent scoping reports of the Australian Higher Education sector have highlighted continual, rapid growth in online enrollments, but also a degree of "blurring" of boundaries, due to the increased adoption of technologies to support the on-campus learning experience (Norton and Cherastidtham, 2014; Norton and Cakitaki, 2016). Changes to Australian funding policy have also enabled more public universities to invest in online offerings (Kemp and Norton, 2014), contributing to the continuing growth of this sector. 
Online modes of study have been found to be equivalent to on-campus environments with respect to key outcomes such as student academic performance (Magagula and Ngwenya, 2004; McPhee and Söderström, 2012) and student satisfaction (Palmer, 2012). However, online offerings also pose some key differences to on-campus modes of study. Accessing course materials online allows unprecedented levels of flexibility and accessibility for students from around the world and overcomes geographical barriers that might prevent students accessing on-campus course offerings (Brown, 1997, 2011; Bates, 2005). The nature of the online education environment also means that course delivery needs to compensate for the lack of immediate physical infrastructure, relying more heavily on asynchronous methods of communication. There is also emerging evidence that online student cohorts differ from on-campus cohorts with respect to factors such as age and work or family commitments (Bailey et al., 2014; Johnson, 2015), which also speaks to the demand for more flexible, career-driven online offerings. The requirements of online students as a distinct demographic are another factor for consideration when planning and developing an online course. Furthermore, from a course development perspective, there is increasing understanding that developing online courses is more complex than merely translating written materials to an online format; it requires careful planning and maximization of available online technologies to cater for a variety of individual differences, student timetables and external commitments, and assessment modes (e.g., Rovai, 2003; Grant and Thornton, 2007; Rovai and Downey, 2010). Online learning does not only differ for students but also carries implications for instructors. Online instruction places varying demands on delivery and feedback methods and relies on different teacher knowledge and skills than face-to-face tuition (Alvarez et al., 2009). It is evident that a sensitive approach catering to both similarities and differences of both modes of study is warranted.

With the abovementioned differences between on-campus and online education in mind, there is a duty for online education providers to continue to research and implement best practice for online modes of study. As fully online offerings continue to develop, new modes of delivery necessitate continual adjustment and evaluation to ensure that courses meet student needs. One such development is the move toward intensive mode courses. Intensive online degree courses (hereafter referred to as "intensive online courses") are those in which students complete a degree entirely online, within an accelerated timeframe compared to the typical on-campus learning experience. Units of study are also delivered in shorter timeframes than the traditional (in an Australian context) 12- or 13-week semester, sometimes comprising 6 or 8 weeks of intensive learning, where a similar amount of material is covered compared with a semester structure. Students typically complete one unit at a time (as compared to four units concurrently for a traditional oncampus semester). Intensive online degree programs have built on the success of MOOCs to help upskill, and in some cases provide certified professional development, over a faster timeframe than typical on-campus university courses (Laurillard, 2016). MOOCs aside, the literature base on intensive online learning for degree programs in particular remains limited. With the potential for tertiary institutions to move more toward this mode of offering, which provides for increased student intake to meet growth demands, there is a need to more comprehensively evaluate the factors that contribute to student and instructor success in an intensive online learning environment. The present integrative review aims to bring together acknowledged best practices in online education, with a view to considering how these may apply in an intensive online education environment. In particular, the elements that comprise a successful online experience for instructors and students, and the provision of student support and well-being services are considered.

\section{ONLINE TEACHING: CRITICAL FACTORS}

As online modes of study continue to expand, there is increasing awareness of the need for competent online instructors. Developing institutional competence for online instruction requires a careful approach to training online instructors and a workload investment in staff training and development (Gregory and Lodge, 2015). While it is acknowledged that face-to-face teaching competencies such as knowledge of curricula and pedagogy do transfer to online contexts, it is also important to recognize the unique competencies required for online teaching success, and the role of institutions in setting instructor duties and responsibilities (Alvarez et al., 2009). Despite much prior research attention exploring the notion of online student readiness, online instructor readiness is now emerging as an equally important construct (Oomen-Early and Murphy, 2009).

There is consensus in prior literature that effective online instruction requires a more flexible approach to skill development, due to the variety of roles and skills applied in online contexts (Bawane and Spector, 2009). Key environmental differences between online and on-campus learning environments also necessitate the development of different online teaching competencies. A sample of existing frameworks for teacher competencies in online education is summarized in Table $\mathbf{1}$ below.

The ability to effectively communicate, manage technology, and deliver and assess content becomes especially important in intensive online environments, where there is less available time to acclimatize to new tools and operating environments. The monitoring of student progress, identification, and followup of issues or barriers are also critical duties for instructors to minimize the likelihood of student disengagement or withdrawal.

Online learning systems employ a variety of online tools, systems, and software, which place new demands on the technical competence of instructors (Volery and Lord, 2000). Modes of communication also differ in online courses, with a greater reliance on asynchronous communication methods (Hung et al., 2010). Live, "virtual" classrooms may also involve remote but instant methods of feedback between student and instructor, facilitated through live chat, video/webcam interactions, and small-group "break-out rooms." The development of student rapport also differs in online contexts, and the nature of how rapport is initiated and maintained in online settings is not always easily comparable to face-to-face teaching. Naturally, assessment and feedback are also delivered in different ways via asynchronous methods when teaching online. Clear assessment 
TABLE 1 | Established teacher competency frameworks in online education.

\begin{tabular}{|c|c|}
\hline Source & Key competencies \\
\hline Dennis et al. (2004) & $\begin{array}{l}\text { - Pedagogy } \\
\text { - Communication } \\
\text { - Discipline expertise } \\
\text { - Technology }\end{array}$ \\
\hline $\begin{array}{l}\text { The International Board of Standards for Training, Performance and } \\
\text { Instruction (Beaudoin, 2015) }\end{array}$ & $\begin{array}{l}\text { - Applying situational leadership } \\
\text { - Managing change to enable innovation } \\
\text { - Persevering through slow or incremental periods of change } \\
\text { - Willingness to advance the online education agenda for the next generation of distance } \\
\text { education professionals. }\end{array}$ \\
\hline UNESCO ICT Competency Framework for teachers (UNESCO, 2011) & $\begin{array}{l}\text { - Ability to teach technological literacy } \\
\text { - Encouraging knowledge deepening } \\
\text { - Knowledge creation } \\
\text { Intended outcomes } \\
\text { - Increased technological literacy } \\
\text { - Ability to apply learnings to real-world problems } \\
\text { - Help students handle challenges of being active citizens }\end{array}$ \\
\hline
\end{tabular}

practices, including communication of deadlines and assessment requirements, have been found to positively influence student engagement and course completion (Thistoll and Yates, 2016).

Institutional and research-based efforts to characterize the competencies required for effective online instruction (e.g., Goodyear et al., 2001; Dennis et al., 2004; Darabi et al., 2006; International Board of Standards for Training, Performance and Instruction, http://ibstpi.org/, as cited in Beaudoin, 2015) suggest a degree of overlap in the conceptualization of the core teacher competencies required for effective online instruction. Some of the most important online teacher competencies drawn from the aforementioned studies include:

- communication skills;

- technological competence;

- provision of informative feedback;

- administrative skills;

- responsiveness;

- monitoring learning;

- providing student support.

Without adequate technological skills, instructors risk being unable to resolve technology-related problems during live class, which may impact student access to learning materials. Communication skills are also paramount (Easton, 2003). Effective instructor-student communication in online learning environments relies on timely and clear interactions through a variety of formats (Easton, 2003), including email, chat, live class questions, and assessment and feedback provision. In the absence of more immediate feedback methods available to on-campus instructors (e.g., face-to-face consultation), the assessment and feedback provided in online learning environments needs to be as clear and valuable as possible to promote student understanding (Darabi et al., 2006). Teacher support online involves effective monitoring of student progress, anticipation and resolution of key learning queries, and establishment and maintenance of rapport. Collectively, these kinds of competencies shape the effectiveness of online instructors and, in turn, the student experience. While these elements are well established as effective practice in online tuition, there exists significantly more pressure on these factors when content delivery, assessment, feedback, and communication occur within a condensed 6- to 8-week timeframe.

In addition to student-related benefits, there is evidence that online instructor training can provide benefits to instructors themselves (Roblyer et al., 2009). These benefits occur both through expansion of direct skills for the instructor (i.e., professional development) to build confidence in online environments, and also through skills that are transferable to on-campus contexts (Roblyer et al., 2009), providing a wider institutional benefit. Roblyer et al. (2009) note a kind of "reverse impact phenomenon" whereby teachers have experienced transferred skills improvements in face-to-face tuition by enhancing online teaching skills. While these authors based the outcomes around K-12 teachers, it is likely that the gains experienced by teachers (e.g., improved self-reflection on teaching and assessment methods; increased sensitivity toward student needs) would be similarly relevant to on-campus tertiary teachers. It is also important, however, to consider the environmental challenges posed by more intensive teaching timeframes. Instructors delivering content in shorter blocks of time have less time to reflect on, adapt and amend content before the next unit delivery, and thus unit re-design and content development can be more of a challenge in intensive online environments.

Effective online instructors have a direct and important role in influencing the student experience, since instructors are often the "face" of an online course. Prior studies have emphasized instructor presence as among the most critical of factors related to student success online (Easton, 2003; Menchaca and Bekele, 2008; Kennette and Redd, 2015; Kim and Thayne, 2015). In the absence of the richness of interactions available to on-campus students, instructors become an even more important "ingredient" in helping to engage, retain, and graduate online students. Instructors also play a key role in motivating students throughout their online study (Bolliger and Martindale, 2004), since instructors may commonly be the only personalized point of contact 
provided to students at any one time. Instructor responsiveness and availability has been highlighted as a key predictor of online student satisfaction, in that lack of timely feedback or slow communication timeframes from instructors detract from student satisfaction online (Bolliger and Martindale, 2004). It is apparent that development of instructor training is a critical component of effective institutional preparation for wholly online courses, so that teachers can develop the range of skills required to teach online successfully.

When considering the applicability of teacher competencies to an intensive online environment, it is reasonable to assume that the faster-paced nature of intensive learning may require greater competence with respect to certain instructor skills. The building of teacher competencies is a process that requires institutional planning and reflection when considering a move to more intensive online degree offerings, so that instructors are supported to flourish and students can benefit from quality instruction. The Technological Pedagogical Content Knowledge (TPACK) model proposed by Mishra and Koehler (2006) (see Figure 1 below) provides a useful framework through which to view teacher competencies across multiple levels, and we can apply this model to consider teacher skills in intensive online environments.

The TPACK model promotes meaningful integration of technology, content knowledge, and pedagogy (Mishra and Koehler, 2006). Thus, an instructor's ability to utilize technology as the basis for timely, responsive and clear feedback becomes even more critical in an intensive online environment, which can be further exacerbated by a lack of time to resolve technical issues or system access problems. Since technology is inherently embedded in content delivery and influential in approaches

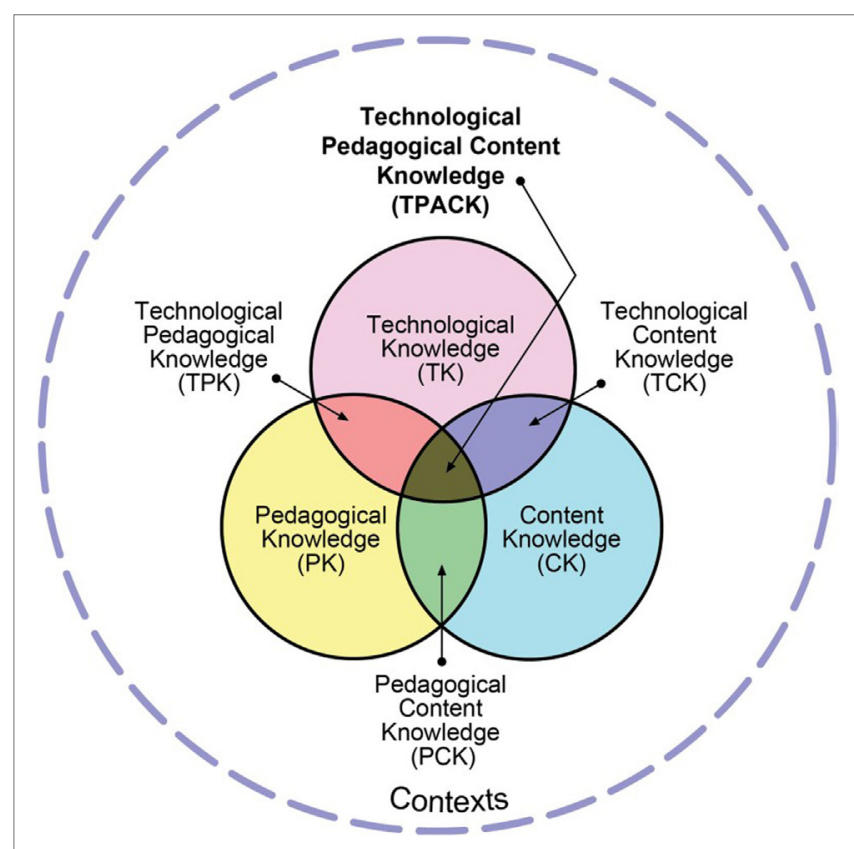

FIGURE 1 | The Technological Pedagogical Content Knowledge (TPACK) model (Mishra and Koehler, 2006). Reproduced by permission of the publisher, (c) 2012 by tpack.org. to teaching, technical competence must also be highlighted alongside content proficiency and pedagogical knowledge for instructors seeking to teach online, especially in intensive environments. It is apparent that the demands on all of these skill areas are likely to be heightened in an intensive delivery setting, and further research to understand the nature of any additional skill demands in intensive online environments would be valuable.

\section{ONLINE LEARNING: CRITICAL FACTORS}

Effective approaches to online education must also take account of baseline learner competencies and characteristics. Demographically, there are consistent differences between oncampus and online students (Bailey et al., 2014). For instance, more women than men appear to choose online modes of study (Price, 2006). Further, online learners are typically older than on-campus students, with many being "mature-age" students between the ages of 25 and 50 (Moore and Kearskey, 2005). This also presents a rich opportunity to enhance the learning environment through incorporation of some of the life experiences of older learners online (Boston and Ice, 2011; O'Shea et al., 2015). Greenland and Moore (2014) also noted the potential for unexpected work commitments and/or busy work schedules to contribute to student intermissions and discontinuations.

With regard to factors that influence student choice to study online, there is evidence that students opting to study online choose flexibility (i.e., convenience) over the perceived value of studying on-campus (Bolliger and Martindale, 2004). This flexibility is likely to be prioritized due to many online students being at a later life stage than younger on-campus students, whereby study must be accommodated around work and family commitments. However, the source of a requirement for flexibility also brings with it additional complications: factors such as age, gender, educational history, work obligations, and family commitments have all been found, in turn, to impact on completion rates in tertiary education settings (Tsay et al., 2000; Colorado and Eberle, 2010).

Becoming an online learner places different demands on students. The fundamental quality and nature of the student experience shifts in online learning environments to a greater reliance on asynchronous modes of communication. Interactions also occur through a variety of methods, including learner-to-content, learner-to-instructor, and learner-to-learner (peer) interaction (Bolliger and Martindale, 2004). This necessitates a more proactive, self-directed approach on the part of students (Brown, 1997; Tsay et al., 2000; Khiat, 2015; Kirmız1, 2015). Self-regulated learning, where students use meta-cognitive skills to plan, implement, and reflect on their learning, have been increasingly associated with better academic achievements (Johnson, 2015; Khiat, 2015). Active engagement in academic materials, and with instructors and peers, has been emphasized as a core component of successful learning for students (Pascarella and Terenzini, 2005). In one study, lack of social interaction was found to be the largest single barrier to student success online (Muilenburg and Berge, 2005). Meaningful connections with the institution are a key ingredient in student engagement (Pascarella and Terenzini, 2005). 
However, not all of the responsibility for effective engagement in online courses lies with the student. There is an institutional and faculty responsibility to create an inclusive, supportive structure where students can engage in social interactions and a sense of (online) community can be fostered, as has been apparent in research findings from Garrison and colleagues in applying and extending the Community of Inquiry model (e.g., Garrison et al., 2000; Aragon, 2003; Garrison and Cleveland-Innes, 2005; Garrison and Arbaugh, 2007) (see Figure 2 below).

This sense of belonging is a key component that impacts student engagement and can act as a buffer against attrition (Oomen-Early and Murphy, 2009). As well as understanding and promoting the factors that can enhance belonging in an online community, faculty also have a responsibility to monitor student progress and address any early signs of difficulty or disengagement (Beaudoin, 2002; Dennen, 2008).

A number of factors and situations can act as barriers to effect student engagement in online study, and online environments have long been known to face higher attrition rates than on-campus modes of study (Oomen-Early and Murphy, 2009). Many of these elements stem from the unique challenges and opportunities of online learning environments discussed above:

- technical difficulties;

- perceived isolation;

- challenges balancing study;

- work and family commitments;

- confusion with content;

- poor academic performance; or

- lack of motivation.

Thus, understanding how best to gauge student readiness or preparedness for online study is a critical institutional responsibility. A range of recent studies have sought to characterize the main factors underlying readiness for online study (Vonderwell, 2004; Watkins et al., 2004; Pillay et al., 2007; Mercado, 2008;

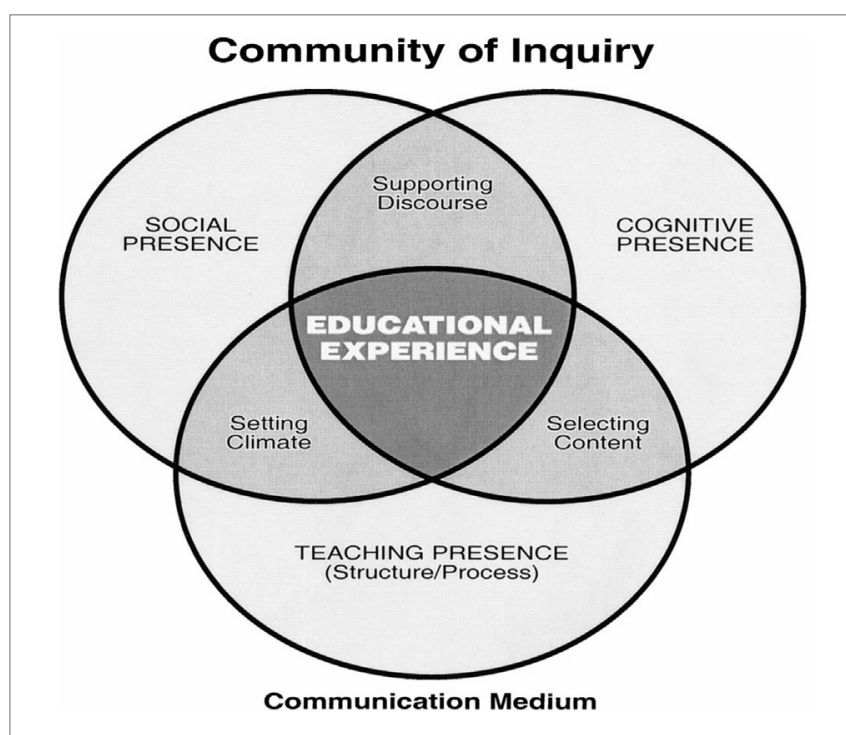

FIGURE 2 | Community of Inquiry model (Garrison et al., 2000). Reproduced with permission from the author.
Dray et al., 2011; Farid, 2014; Wladis et al., 2016). Collectively, these studies emphasize the importance of technical skills, effective time management, individual differences (especially selfdirected or self-regulated learning), financial means, and online self-efficacy as elements of readiness. A range of measures have also been developed and validated to assess student readiness for online learning (Kerr et al., 2006; Mercado, 2008; Hung et al., 2010; Dray et al., 2011), but there is scope in future research to consider the notion of student readiness more directly, as it relates to readiness for intensive online learning. In this mode, one could argue that there is an increased responsibility for faculty to screen students on commencement, to pre-empt and remedy potential barriers to a successful online study experience. Further, a more holistic approach to defining student readiness that encompasses key psychological, technological, situation, and learning-related contributors to readiness for intensive online study is recommended.

Intensive online courses are likely to involve many of the same benefits and challenges for students as non-intensive courses. However, it is of note that the faster pace of the learning environment inherent in intensive courses means that both students and instructors have less time to address any key concerns, provide remedial support, or rectify any unintended technical or learning delays. Thus, the process of monitoring student progress and potential barriers is paramount in intensive online learning environments.

\section{ONLINE ENVIRONMENT: STUDENT SUPPORT AND WELL-BEING SERVICES}

Consideration of student support services becomes paramount in intensive online environments, where disruptions to technology or lack of support services can pose a significant barrier to student engagement in learning. Students completing courses wholly online are often limited in their access to the entire variety of support services a university offers, compared to their on-campus counterparts (Lee, 2010). The "four pillars" of supporting student success (see Figure 3 below) are often the intangibles that educators might take for granted when providing fully online courses. These pillars include online-friendly academic supports (Coonin et al., 2011; Huwiler, 2015), assistance with navigating technology (Lee, 2010), health and well-being facilities (Anderson, 2008), and a sense of belongingness, or community (Kumar and Heathcock, 2014).

Ensuring a positive and rewarding experience for online students, particularly those enrolled within intensive online courses, is contingent upon the institutional provider offering equitable support structures that are also appropriately translated into the online environment (Pullan, 2011). Being already prone to higher attrition rates, fully online students adopting study via intensive modes have increased expectations of their instructors, and the course learning environment more broadly, to provide the necessary infrastructure required to manage the increased workload. Therefore, tertiary providers choosing to deliver fully online courses, particularly intensive courses, need to ensure that these four pillars are prioritized equivalently to the translation 


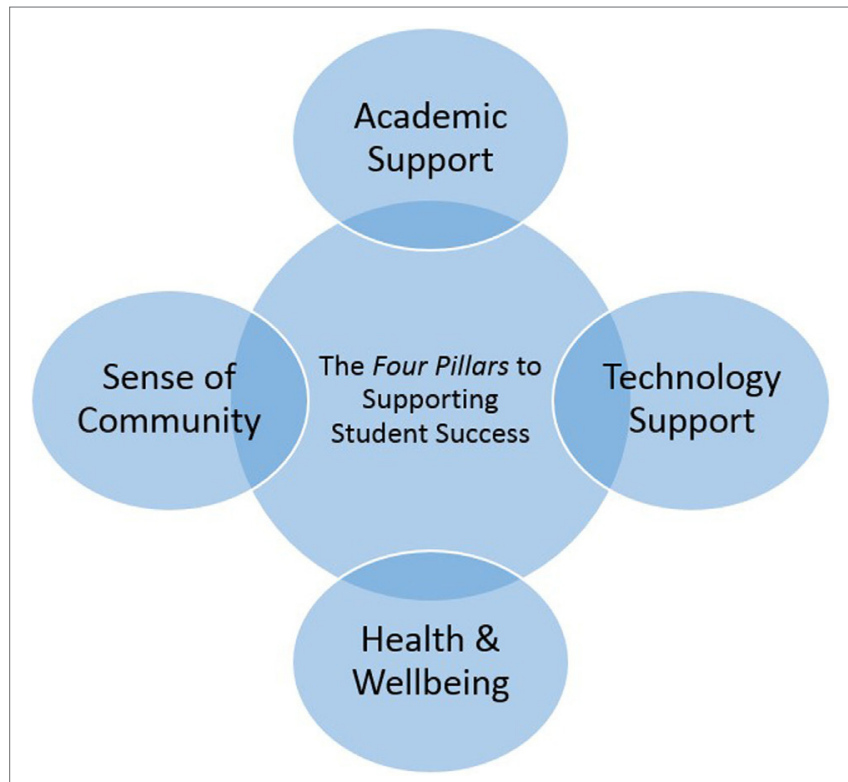

FIGURE 3 | The "four pillars" to supporting student success.

of content into online platforms in order to maximize student success and reduce risks for attrition.

The first pillar, and arguably the most crucial support an institution can offer to online students, revolves around online-friendly academic resources and ample opportunities for studentinstructor interaction (Cannady, 2015). The success of completing a tertiary degree online strongly depends on the student's ability to work autonomously and manage their time effectively (Wang et al., 2013). Beyond the personal qualities students must possess to succeed in an online course, as previously discussed, there is also a growing need for the institution offering the course to provide appropriate online-friendly academic scaffolding that supports their students throughout their learning (Lee and Choi, 2011). This includes, but is not limited to, detailed orientation services, and comprehensive library resources.

Providing orientation services, especially for online students, is essential in order to adequately integrate incoming cohorts into their new online learning environment (Cho, 2012). Research, albeit limited, has consistently shown that orientation programs have improved student retention and academic performance both on- and off-campus (House and Kuchynka, 1997; Williford et al., 2001; Wilson, 2005). When looking specifically at online courses, the factors that contribute to a successful orientation include comprehensive overviews of the course structure, recommended time commitments and expectation of students, familiarization with required instructional media and software, and guidance on the communication tools needed for student-staff interactions. Delivering this information in an online environment requires a substantial rethink of the way in which these programs are designed (Smyth and Lodge, 2012). Despite the challenges, providing these resources before a student commences their course has been shown to be critical for reducing early drop-out rates, increasing self-confidence, and enhancing the students' sense of belonging (Tomei et al., 2009). However, many institutions that offer online courses do not make their orientation program mandatory before commencement, while some choose not to deliver an orientation program at all. In fact, one study has suggested up to $29 \%$ of institutions only offer on-campus orientation programs, despite also offering fully online courses (Cannady, 2015), perhaps due to the difficulty in developing effective online orientation. This rate is particularly concerning given there is strong evidence to show that comprehensive orientation programs are vital to supporting online student success.

Comprehensive, course-specific resources created to improve students' academic performance are also pivotal to student success, and are best delivered when strong collaborations between online instructional staff and the institution's librarians are prioritized (Arnold et al., 2002; Kumar and Heathcock, 2014). Many university libraries provide an abundance of resources that assist new students transitioning into tertiary life (Arnold et al., 2002). However, if online course providers are unaware of the technological and/or literacy competencies of their students, these library resources may not be properly disseminated to incoming cohorts. This is problematic for fully online courses, particularly those offered in intensive modes where demands are greater, if the only exposure to their institution required is via their course's learning management system (LMS). Targeted training programs and easy access to comprehensive resources available online is therefore vital to improving student success in intensive online learning environments; simply providing generic resources via a course's LMS without proper instruction may not be sufficient to meet online student needs (Kumar and Heathcock, 2014). It is important that instructors gauge their student's competencies before commencing the course so that any necessary gaps, particularly those easily fulfilled with existing library resources, can be addressed appropriately.

The second pillar, yet one of the most immediate and unique hurdles for online students, is the need to provide adequate technical scaffolding in order to prepare students for learning in an online-only environment (Shea et al., 2005). Tertiary institutions offering fully online courses need to assure that all technology requirements are clearly communicated to students before commencing the course, and that ongoing technical support is provided to reduce delay in meeting course expectations. This is particularly important for intensive modes of online study where assessment deadlines leave little to no room for technical-based hurdles. The strong relationship between a student's acceptance of technology and their perceived satisfaction with online courses is also important to consider, as this may pose additional hurdles to incoming cohorts unaccustomed to learning in an online environment (Lee, 2010). As emphasized earlier in this review, where students or instructors lack the required technical competence, this can pose a significant and sometimes insurmountable barrier, contributing to student discontinuation or disengagement from the course. Thus, adopting a user-friendly learning environment and flexible online technical support is critical for intensive online courses in order to increase student retention and engagement.

Beyond the need to overcome technological obstacles are the pressures of academic achievement, transitioning to university life and time management; all which benefit from the third pillar that is health and well-being support. These factors 
create increasing stress among students, both on- and offline (Robotham and Julian, 2006). University student cohorts have been found to have concerning rates of mental health issues (Andrews and Wilding, 2004; Bayram and Bilgel, 2008; Hjeltnes et al., 2015), and online student cohorts, particularly those adjusting to intensive study modes, face comparable challenges. In response, several efforts have been made by universities to support students and promote positive mental health and wellbeing in an attempt to combat increasing psychological distress (Regehr et al., 2013). One example is the effort to extend support programs to online students which are already available to on-campus students, such as personal counseling and career services (Dare et al., 2005; Lapadula, 2010). However, this solution often does not account for the many online students who are not in the required geographical district needed to access these services, in person or via phone.

One potential solution to the geographical hurdle is for institutions to invest in online counseling or self-help services, to reach beyond their usual audience who utilize traditional face-to-face services (Tokatlidis et al., 2011). This option holds promise as a means of creating services with sufficient flexibility to allow access for students from a diverse range of locations. Another wide-reaching strategy demonstrating increasing efficacy among university students is mindfulness. In recent years, mindfulness - the practice of bringing attention to the present moment, non-judgementally-has substantially grown in popularity, particularly within education contexts where research has shown that mindfulness can benefit students experiencing high rates of psychological distress (Cavanagh et al., 2013). The efficacy of mindfulness-based practices within primary and secondary schools (Zenner et al., 2014), as well as at tertiary level (Regehr et al., 2013), has been well documented and shows promising results in improving resilience against common student-related stressors. The benefits of advancing technology has also seen an increasing number of online mindfulness programs rolled out, which have positive implications for the growing popularity of fully online tertiary courses (Sable, 2010). Yet despite this, the benefits of integrating online mindfulness-based practices into completely online courses is scarcely researched. The need for evidence-based interventions and prevention strategies is especially crucial given that literature suggests around $50 \%$ of university students experience significant levels of psychological distress while enrolled (Regehr et al., 2013). Provision of psychological services is made more difficult for online students who may not otherwise have access to any other form of mental health support (Lapadula, 2010). Therefore, more research is required into appropriate prevention and intervention strategies for high rates of distress among students involved in intensive online learning, given the added pressures they face with shorter course deadlines and being physically segregated from their peers.

The last pillar required to support student success comes with prioritizing a sense of belongingness and community to any fully online cohort. Fostering open dialog between students, instructors, and their fellow classmates is essential to online learning which can often be taken for granted during the implementation of online courses (Coomey and Stephenson, 2001).
As alluded to earlier in this review, online students require personalized, timely feedback on assessments (Li and Beverly, 2008; Lee, 2010), equivalent community-like interactions with peers via social networking platforms such as Facebook and Twitter (Roblyer et al., 2010; Akcaoglu and Bowman, 2016; Tang and Hew, 2017), and ideally 24-h academic and technical support services (Lorenzo and Moore, 2002) in order to succeed in online learning. In particular, research has identified that adequate quality and quantity of interaction between a student and their instructor is associated with increased student course satisfaction (Lee, 2010; Ralston-Berg et al., 2015). Therefore, it is necessary for institutions to prioritize offering effective means for communication within the online learning environment, not bound by physical or geographical segregation. For example, one study has suggested that the use of asynchronous activities, such as introducing yourself via video posts and conducting online discussion forums, may be useful in combatting the issues of isolation and lack of a "sense of community" commonly found among online students (Trespalacios and Rand, 2015). Given the shorter timeframe required for students to meet course deadlines via intensive modes, it becomes critical that students feel continuously supported, and that this support is fostered by the infrastructure of their online learning environment. Further research has also suggested that there are benefits to including students and instructors' input into the development and implementation of online courses, which can assist in keeping students engaged and thus achieve success (Roby et al., 2013). Each of these pillars, particularly when equally prioritized in fully online course delivery, ultimately best equip students to succeed in their course from orientation through to graduation.

\section{SUMMARY: APPLICATIONS TO INTENSIVE ONLINE LEARNING ENVIRONMENTS}

In reflecting on the discussion points raised in the current review, it is apparent that online environments and intensive online environments are likely to share many "ingredients" in common. Both contexts share similar modes of communication, structures, learning materials and methods, assessment principles, and skills requirements of both instructors and students. Nevertheless, the compressed timeframes involved in intensive online learning mean that the reliance on effective communication, technology, learning, and feedback strategies increases, and the corresponding demands on teacher and learner competencies are higher.

Instructor presence remains a critical factor in all modes of online study, and particularly so in intensive online environments, where instructors need to work to establish and maintain student engagement. Pedagogical approaches need to account for learner competencies, characteristics, and preferred learning approaches. This is especially important given the emerging demographic differences between online and on-campus cohorts. Intensive online learning environments should take account of potential barriers that can lead to increased attrition, such as perceived isolation, competing work/family commitments, poor motivation, lack of engagement with content, and technical challenges. There are particular time pressures evident in an intensive online course 
when needing to identify and rectify such barriers, and regular monitoring of student progress can help to quickly identify and address potential concerns. Providing comprehensive orientation services is key to ensure students are adequately informed and linked to ongoing support services. Communication plays a pivotal role in enhancing the online learning experience through peer-to-peer and student-to-instructor dialog. Ongoing flexible technical support is also vital to manage any technical issues that arise. Finally, well-being services and the provision of online well-being content such as mindfulness resources are important steps toward the prevention of online student mental health concerns.

On a more general note, a flexible and responsive approach to all activities is critical in intensive online environments. Where there are student or instructor skills gaps, it becomes more timecritical to identify and address these, or potential barriers can become a greater risk of student attrition. Likewise, if students are not able to adopt a proactive approach to time management and prioritize study deadlines, the risk of overwhelm and stress increases. Academically, understanding key content and successfully completing assessment tasks becomes of greater importance in the intensive online environment. Future research would benefit from understanding any specific factors related to student and instructor readiness for intensive online study, so that institutions adopting intensive study modes can provide the maximum chance of a successful experience for all involved.

It is apparent that intensive online courses offer a range of benefits to students and staff, including accessibility, opportunities for embracing new technologies, and promoting independent, self-regulated learning. These benefits need to be considered alongside some of the known barriers associated with online education; potential student disengagement, work-life balance difficulties for students working full-time, and technological challenges for both students and instructors. It is imperative to continue to monitor and meet student needs that are particular to the online environment, so that online courses can adapt to changing future needs. With the move for tertiary institutions to

\section{REFERENCES}

Akcaoglu, M., and Bowman, N. D. (2016). Using instructor-led Facebook groups to enhance students' perceptions of course content. Comput. Human Behav. 65, 582-590. doi:10.1016/j.chb.2016.05.029

Allen, E., and Seaman, J. (2017). Digital Learning Compass: Distance Education Enrollment Report 2017. Babson Survey Research Group, e-Literate, and WCET.

Alvarez, I., Guasch, T., and Espasa, A. (2009). University teacher roles and competencies in online learning environments: a theoretical analysis of teaching and learning practices. Eur. J. Teach. Educ. 32, 321-336. doi:10.1080/ 02619760802624104

Anderson, T. (2008). The Theory and Practice of Online Learning. Athabasca, Alberta, Canada: AU Press, Athabasca University.

Andrews, B., and Wilding, J. M. (2004). The relation of depression and anxiety to life-stress and achievement in students. Br. J. Psychol. 95, 509-521. doi:10.1348/ 0007126042369802

Aragon, S. (2003). Creating social presence in online environments. Encycl. Distance Online Learn. 11, 1-9. doi:10.4018/978-1-60566-198-5.ch280

Arnold, J., Sias, J., and Zhang, J. (2002). Bringing the library to the students. J. Libr. Adm. 37, 27-37. doi:10.1300/J111v37n01_04

Bailey, M., Ifenthaler, D., Gosper, M., and Kretzschmar, M. (2014). "Factors influencing tertiary students' choice of study mode," in Rhetoric and Reality: Critical consider more intensive modes of online degree study comes an increased responsibility to understand how best to prepare students, instructors, and student support mechanisms to succeed in intensive online learning environments. Consideration of the factors discussed in the current review will guide institutions and educators to maximize student success in intensive online courses as this sector continues to rapidly evolve. Future research is well positioned to continue deepening understanding of best practice as it applies to intensive online education.

\section{AUTHOR CONTRIBUTIONS}

CR wrote and refined the introductory, instructor- and studentfocused, and conclusion sections of the review. DA wrote and refined the component relating to student support and well-being. All team members were involved in publication planning, reading of drafts and suggestions for changes, and feedback on the final publication draft. SM, MM, and JL were additionally involved in providing strategic advice on directions for the paper, and the role of the paper within the research team agenda.

\section{ACKNOWLEDGMENTS}

The authors wish to thank Professor Kim Cornish and Associate Professor Matthew Mundy for supporting the creation of the Monash Online - Psychology Education Division (MO-PED) team and associated research outputs. The authors also wish to acknowledge funding support supplied via the Monash Pearson Alliance. The team also wishes to thank Leah Braganza and Tony Mowbray for their time in providing feedback on the draft manuscript.

\section{FUNDING}

Completion of the current review was funded by the School of Psychological Sciences, Faculty of Medicine Nursing and Health Sciences, Monash University.

Perspectives on Educational Technology, eds B. Hegarty, J. McDonald, and S.-K. Loke. Proceedings ascilite Dunedin 2014, 251-261.

Bates, A. W. (2005). Technology, e-Learning and Distance Education. London: Routledge.

Bawane, J., and Spector, J. M. (2009). Prioritization of online instructor roles: implications for competency-based teacher education programs. Distance Educ. 30, 383-397. doi:10.1080/01587910903236536

Bayram, N., and Bilgel, N. (2008). The prevalence and socio-demographic correlations of depression, anxiety and stress among a group of university students. Soc. Psychiatry Psychiatr. Epidemiol. 43, 667-672. doi:10.1007/s00127-0080345-X

Beaudoin, M. F. (2002). Learning or lurking? Tracking the "invisible" online student. Internet Higher Educ. 5, 147-155. doi:10.1016/S1096-7516(02)00086-6

Beaudoin, M. F. (2015). Distance education leadership in the context of digital change. Quart. Rev. Dist. Educ. 16, 33-44.

Bolliger, D. U., and Martindale, T. (2004). Key factors for determining student satisfaction in online courses. Int. J. E-Learn. 6, 61-67.

Boston, W. E., and Ice, P. (2011). Assessing retention in online learning: an administrative perspective. Online J. Distance Learn. Adm. 14, 1-12.

Brown, A. (1997). Features of an effective online course. Aust. J. Educ. Technol. $13,115-126$.

Brown, V. (2011). Changing demographics of online courses. US-China Educ. Rev. $8,460-467$. 
Cannady, R. E. (2015). Under the microscope: looking at libraries and online orientations. J. Libr. Inf. Serv. Distance Learn. 9, 289-303. doi:10.1080/1533290X. 2015.1095266

Cavanagh, K., Strauss, C., Cicconi, F., Griffiths, N., Wyper, A., and Jones, F. (2013). A randomised controlled trial of a brief online mindfulness-based intervention. Behav. Res. Ther. 51, 573-578. doi:10.1016/j.brat.2013.06.003

Cho, M.-H. (2012). Online student orientation in higher education: a developmental study. Educ. Technol. Res. Dev. 60, 1051-1069. doi:10.1007/s11423-012-9271-4

Colorado, J. T., and Eberle, J. (2010). Student demographics and success in online learning environments. Emporia State Res. Stud. 46, 4-10.

Coomey, M., and Stephenson, J. (2001). Online learning: it is all about dialogue, involvement, support and control - according to the research. Teach. Learn. Online Pedagogies New Technol. 37-52. Available at: http://citeseerx.ist.psu.edu/ viewdoc/download?doi=10.1.1.458.4620\&rep=rep1\&type $=$ pdf

Coonin, B., Williams, B. F., and Steiner, H. (2011). Fostering library as place for distance students: best practices from two universities. Internet Ref. Serv. Q. 16, 149-158. doi:10.1080/10875301.2012.618796

Darabi, A. A., Sikorski, E. G., and Harvey, R. B. (2006). Validated competencies for distance teaching. Distance Education 27, 105-122. doi:10.1080/01587910600654809

Dare, L., Zapata, L. P., and Thomas, A. G. (2005). Assessing the needs of distance learners: a student affairs perspective. New Dir. Stud. Serv. 2005, 39-54. doi: $10.1002 /$ ss. 183

Dennen, V. P. (2008). Pedagogical lurking: student engagement in non-posting discussion behavior. Comput. Human Behav. 24, 1624-1633. doi:10.1016/j. chb.2007.06.003

Dennis, B., Watland, P., Pirotte, S., and Verday, N. (2004). "Role and competencies of the e-tutor," in In Proceedings of the Networked Learning Conference 2004. Available at: https://orbi.ulg.ac.be/bitstream/2268/12722/1/ DENIS_WATLAND_PIROTTE_VERDAY_Roles_and_competencies_of_ the_tutor_30_03_2009.pdf

Dray, B. J., Lowenthal, P. R., Miszkiewicz, M. J., Ruiz-Primo, M. A., and Marczynski, K. (2011). Developing an instrument to assess student readiness for online learning: a validation study. Distance Educ. 32, 29-47. doi:10.1080/01587919. 2011.565496

Easton, S. S. (2003). Clarifying the instructor's role in online distance learning. Commun. Educ. 52, 87-105. doi:10.1080/03634520302470

Farid, A. (2014). Student online readiness assessment tools: a systematic review approach. Electron. J. E Learn. 12, 375-382.

Garrison, D., Anderson, T., and Archer, W. (2000). Critical inquiry in a text-based environment: computer conferencing in higher education. Internet Higher Educ. 2-3, 87-105. doi:10.1016/\$1096-7516(00)00016-6

Garrison, D. R., and Arbaugh, J. B. (2007). Researching the community of inquiry framework: review, issues, and future directions. Internet Higher Educ. 10, 157-172. doi:10.1016/j.iheduc.2007.04.001

Garrison, D. R., and Cleveland-Innes, M. (2005). Facilitating cognitive presence in online learning: interaction is not enough. Am. J. Distance Educ. 19, 133-148. doi:10.1207/s15389286ajde1903

Goodyear, P. M., Salmon, G., Spector, J. M., Steeples, C., Tickner, S., Goodyear, P., et al. (2001). Competencies for online teaching: a special report. Educ. Technol. Res. Dev. 49, 65-72. doi:10.1007/BF02504508

Grant, M. R., and Thornton, H. R. (2007). Best practices in undergraduate adult-centered online learning: mechanisms for course design and delivery. MERLOT J. Online Learn. Teach. 3, 346-356.

Greenland, S. J., and Moore, C. (2014). Patterns of online student enrolment and attrition in Australian open access online education: a preliminary case study. Open Praxis 6, 45-54. doi:10.5944/openpraxis.6.1.95

Gregory, M. S.-J., and Lodge, J. M. (2015). Academic workload: the silent barrier to the implementation of technology-enhanced learning strategies in higher education. Distance Educ. 36, 210-230. doi:10.1080/01587919.2015.1055056

Hjeltnes, A., Binder, P.-E., Moltu, C., and Dundas, I. (2015). Facing the fear of failure: an explorative qualitative study of client experiences in a mindfulness-based stress reduction program for university students with academic evaluation. Int. J. Qual. Stud. Health Wellbeing 10, 1-15. doi:10.3402/qhw.v10.27990

House, J. D., and Kuchynka, S. J. (1997). The effects of a freshmen orientation course on the achievement of health sciences students. J. Coll. Stud. Dev. 38, $540-542$.
Hung, M. L., Chou, C., Chen, C. H., and Own, Z. Y. (2010). Learner readiness for online learning: scale development and student perceptions. Comput. Educ. 55, 1080-1090. doi:10.1016/j.compedu.2010.05.004

Huwiler, A. G. (2015). Library services for distance students: opportunities and challenges. J. Libr. Inf. Serv. Distance Learn. 9, 275-288. doi:10.1080/ 1533290X.2015.1111283

Johnson, G. M. (2015). On-campus and fully-online university students: comparing demographics, digital technology use and learning characteristics. J. Univ. Teach. Learn. Pract. 12, 11-51.

Kemp, D., and Norton, A. (2014). Review of the Demand Driven Funding System Report.

Kennette, L. N., and Redd, B. R. (2015). Instructor presence helps bridge the gap between online and on-campus learning. Coll. Q. 18.

Kerr, M. S., Rynearson, K., and Kerr, M. C. (2006). Student characteristics for online learning success. Internet Higher Educ. 9, 91-105. doi:10.1016/j. iheduc.2006.03.002

Khiat, H. (2015). Measuring self-directed learning: a diagnostic tool for adult learners. J. Univ. Teach. Learn. Pract. 12. Available at: http://ro.uow.edu.au/ jutlp/vol12/iss $2 / 2$

Kim, Y., and Thayne, J. (2015). Effects of learner-instructor relationship-building strategies in online video instruction. Distance Educ. 36, 100-114. doi:10.1080/ 01587919.2015 .1019965

Kırmız1, Ö (2015). The influence of learner readiness on student satisfaction and academic achievement in an online program at higher education. Turk. Online J. Educ. Technol. 14, 133-142.

Kumar, S., and Heathcock, K. (2014). "Information literacy support for online students in higher education," in Handbook of Research on Transnational Higher Education, eds S. Mukerji and P. Tripathi (Hershey, PA: IGI Global), 624-640.

Lapadula, M. (2010). A comprehensive look at online student support services for distance learners. Am. J. Distance Educ. 17, 119-128. doi:10.1207/ S15389286AJDE1702

Laurillard, D. (2016). The educational problem that MOOCs could solve: professional development for teachers of disadvantaged students. Res. Learn. Technol. 24, 527. doi: $10.3402 /$ rlt.v24.29369

Lee, J.-W. (2010). Online support service quality, online learning acceptance, and student satisfaction. Internet Higher Educ. 13, 277-283. doi:10.1016/j. iheduc.2010.08.002

Lee, Y., and Choi, J. (2011). A review of online course dropout research: Implications for practice and future research. Educ. Technol. Res. Dev. 59, 593-618. doi:10.1007/s11423-010-9177-y

Li, C.-S., and Beverly, I. (2008). An overview of online education: attractiveness, benefits, challenges, concerns and recommendations. Coll. Stud. J. 42, 449-458.

Lorenzo, G., and Moore, J. (2002). The Sloan Consortium Report to the Nation: Five Pillars of Quality Online Education. New York, NY: Alfred P. Sloan Foundation.

Magagula, C. M., and Ngwenya, A. P. (2004). A comparative analysis of the academic performance of distance and on-campus learners. Turk. Online J. Distance Educ. 5, 1-11.

McPhee, I., and Söderström, T. (2012). Distance, online and campus higher education: reflections on learning outcomes. Campus Wide Inf. Syst. 29, 144-155. doi:10.1108/10650741211243166

Menchaca, M. P., and Bekele, T. A. (2008). Learner and instructor identified success factors in distance education. Distance Educ. 29, 231-252. doi: $10.1080 / 01587910802395771$

Mercado, C. A. (2008). Readiness assessment tool for an elearning environment implementation. Spec. Issue Int. J. Comput. Internet Manage. 16, 18.1-18.11.

Mishra, P., and Koehler, M. (2006). Technological pedagogical content knowledge: a framework for teacher knowledge. Teach. Coll. Rec. 108, 1017-1054. doi:10.1111/j.1467-9620.2006.00684.x

Moore, M. G., and Kearskey, G. (2005). Distance Education: A Systems View. Belmont: Wadsworth Publishing.

Muilenburg, L. Y., and Berge, Z. L. (2005). Student barriers to online learning: a factor analytic study. Distance Educ. 26, 29-48. doi:10.1080/01587910500081269

Norton, A., and Cakitaki, B. (2016). Mapping Australian Higher Education 2016. Carlton: Grattan Institute.

Norton, A., and Cherastidtham, I. (2014). Mapping Australian Higher Education, 2014-2015. Grattan Institute. Available at: http://grattan.edu.au/report/ mapping-australian-higher-education-2014-15/ 
Oomen-Early, J., and Murphy, L. (2009). Self-actualization and e-learning: a qualitative investigation of university faculty's perceived barriers to effective online instruction. Int. J. E Learn. 8, 223-240.

O'Shea, S., Stone, C., and Delahunty, J. (2015). "I 'feel' like I am at university even though I am online." Exploring how students narrate their engagement with higher education institutions in an online learning environment. Distance Educ. 36, 41-58. doi:10.1080/01587919.2015.1019970

Palmer, S. (2012). Understanding the context of distance students: differences in on- and off-campus engagement with an online learning environment. J. Open Flexible Distance Learn. 16, 70-82.

Pascarella, E. T., and Terenzini, P. T. (2005). How College Affects Students. San Francisco, CA: Jossey-Bass.

Pillay, H., Irving, K., and Tones, M. (2007). Validation of the diagnostic tool for assessing tertiary students' readiness for online learning. Higher Educ. Res. Dev. 26, 217-234. doi:10.1080/07294350701310821

Price, L. (2006). Gender differences and similarities in online courses: challenging stereotypical views of women. J. Comput. Assist. Learn. 22, 349-359. doi:10.1111/j.1365-2729.2006.00181.x

Pullan, M. (2011). Online support services for undergraduate millennial students. J. Higher Educ. Theory Pract. 11, 66-84.

Ralston-Berg, P., Buckenmeyer, J., Barczyk, C., and Hixon, E. (2015). Students' perceptions of online course quality: how do they measure up to the research? Internet Learn. J. 4, 38-55.

Regehr, C., Glancy, D., and Pitts, A. (2013). Interventions to reduce stress in university students: a review and meta-analysis. J. Affect. Disord. 148, 1-11. doi:10.1016/j.jad.2012.11.026

Roblyer, M. D., McDaniel, M., Webb, M., Herman, J., and Witty, J. V. (2010). Findings on Facebook in higher education: a comparison of college faculty and student uses and perceptions of social networking sites. Internet Higher Educ. 13, 134-140. doi:10.1016/j.iheduc.2010.03.002

Roblyer, M. D., Porter, M., Bielefeldt, T., and Donaldson, M. B. (2009). “Teaching online made me a better teacher": studying the impact of virtual course experiences on teachers' face-to-face practice. J. Comput. Teach. Educ. 25, 121-126.

Robotham, D., and Julian, C. (2006). Stress and the higher education student: a critical review of the literature. J. Further Higher Educ. 30, 107-117. doi:10.1080/03098770600617513

Roby, T., Ashe, S., Singh, N., and Clark, C. (2013). Shaping the online experience: how administrators can influence student and instructor perceptions through policy and practice. Internet Higher Educ. 17, 29-37. doi:10.1016/j. iheduc.2012.09.004

Rovai, A. P. (2003). In search of higher persistence rates in distance education online programs. Internet Higher Educ. 6, 1-16. doi:10.1016/S1096-7516(02)00158-6

Rovai, A. P., and Downey, J. R. (2010). Why some distance education programs fail while others succeed in a global environment. Internet Higher Educ. 13, 141-147. doi:10.1016/j.iheduc.2009.07.001

Sable, D. (2010). "Contemplative interaction: a key to transformative learning online," in Transformative Learning and Online Education: Aesthetics, Dimensions and Concepts, eds T. Yuzer and G. Kurubacak (Hershey, PA: IGI Global), 260-281.

Shea, P., Pickett, A., and Li, C. S. (2005). Increasing access to higher education: a study of the diffusion of online teaching among 913 college faculty. Int. Rev. Res. Open Distance Learn. 6, 1-28.

Smyth, E., and Lodge, J. M. (2012). Orientation online: an online introduction to university for assisting commencing students transition to higher education. Int. J. First Year Higher Educ. 3, 83-90. doi:10.5204/intjfyhe.v3i1.104
Tang, Y., and Hew, K. F. (2017). Using Twitter for education: beneficial or simply a waste of time? Comput. Educ. 106, 97-118. doi:10.1016/j.compedu.2016.12.004

Thistoll, T., and Yates, A. (2016). Improving course completions in distance education: an institutional case study. Distance Educ. 37, 180-195. doi:10.1080/ 01587919.2016 .1184398

Tokatlidis, O., Kinna, J., Rousseau, F., Lulla, R., and Wilson, G. (2011). Introducing Ask counselling: an online question and answer service for university students. J. Aust. N Z Stud Serv Assoc. 38, 33-40.

Tomei, L. A., Hagle, H., Rineer, A., Mastandrea, L. A., and Scollon, J. (2009). Do orientation materials help students successfully complete online courses? Int. J. Commun. Technol. Educ. 5, 73-89. doi:10.4018/jicte.2009040107

Trespalacios, J., and Rand, J. (2015). Using asynchronous activities to promote sense of community and learning in an online course. Int. J. Online Pedagogy Course Des. 5, 1-13. doi:10.4018/IJOPCD.2015100101

Tsay, M.-H., Morgan, G., and Quick, D. (2000). Predicting students' ratings of the importance of strategies to facilitate self-directed distance learning in Taiwan. Distance Education 21, 49-65. doi:10.1080/0158791000210104

UNESCO. (2011). UNESCO ICT Competency Framework for Teachers, ed. P. Hine. 2nd Edn. Paris, France: UNESCO.

Volery, T., and Lord, D. (2000). Critical success factors in online education. Int. J. Educ. Manage. 14, 216-223. doi:10.1108/09513540010344731

Vonderwell, S. (2004). Online learning: student role and readiness. Turk. Online J. Educ. Technol. 3, 38-42.

Wang, C.-H., Shannon, D. M., and Ross, M. E. (2013). Students' characteristics, self-regulated learning, technology self-efficacy, and course outcomes in online learning. Distance Education 34, 302-323. doi:10.1080/01587919.2013. 835779

Watkins, R., Leigh, D., and Triner, D. (2004). Assessing readiness for e-learning. Perform. Improv. Q. 17, 66-79. doi:10.1111/j.1937-8327.2004.tb00321.x

Williford, M. A., Chapman, L. C., and Kahrig, T. (2001). The university experience course: a longitudinal study of student performance, retention, and graduation. J. Coll. Stud. Retention Res. Theory Pract. 2, 327-340. doi:10.2190/ K7K9-91EG-E6F9-EVMK

Wilson, S. (2005). Improving retention and success: a case study approach for practical results. J. Coll. Stud. Retention 7, 3-4. doi:10.2190/7EW7-X9HH-6UE6EK5H

Wladis, C., Conway, K. M., and Hachey, A. C. (2016). Assessing readiness for online education - research models for identifying students at risk. Online Learn. 20, 97-109. doi:10.24059/olj.v20i3.980

Zenner, C., Herrnleben-Kurz, S., and Walach, H. (2014). Mindfulness-based interventions in schools - a systematic review and meta-analysis. Front. Psychol. 5:603. doi:10.3389/fpsyg.2014.00603

Conflict of Interest Statement: The authors declare that the research was conducted in the absence of any commercial or financial relationships that could be construed as a potential conflict of interest.

Copyright (c) 2017 Roddy, Amiet, Chung, Holt, Shaw, McKenzie, Garivaldis, Lodge and Mundy. This is an open-access article distributed under the terms of the Creative Commons Attribution License (CC BY). The use, distribution or reproduction in other forums is permitted, provided the original author(s) or licensor are credited and that the original publication in this journal is cited, in accordance with accepted academic practice. No use, distribution or reproduction is permitted which does not comply with these terms. 